\title{
Transfer of Dietary Spiramycin into the Eggs and its Residue in the Liver of Laying Hen
}

\author{
Minoru Yoshida*, Daisaku Kubota*, Shoichi Yonezawa**. Hisashi NaKamura**, \\ Hayami AzECHI** and Nobuyuki TERAKADO**
}

Amount of residue of dietary antibiotics, chlortetracycline and spiramycin, in edible parts of poultry and speed of disappearance of the residue after the withdrawal of dietary antibiotics were determined and reported in the previous paper ${ }^{1}$. In this paper, the amount of transfer of dietary antibiotic into eggs of laying hen, its residue in the liver, and the speed of disappearance of the antibiotic from eggs and the liver after withdrawal of the dietary antibiotic are reported.

It was revealed in the previous paper ${ }^{1)}$ that considerable amount of dietary antibiotic was found in the liver of broiler during the feeding period of extremely high level of dietary antibiotic and it remained for several days after the withdrawal of the dietary antibiotic, although little amount of antibiotic was found in the muscles. The findings suggested that some of antibiotic might be transferred into eggs when the antibiotic was fed at high dietary level.

\section{Experimental}

Two experiments were carried out in January, 1969 and in January, 1970, respectively.

Test material and experimental diet: The premix of spiramycin as used in the previous experiment ${ }^{1 /}$ with broiler was mixed in the basal layer diet at the level of 0,20 , 500 and 1,000 ppm in Experiment 1 and at the level of $0,20,50,100,200,500$ and 1,000 ppm in Experiment 2. The basal layer diet composed of $50 \%$ of yellow corn, $17 \%$ of milo, $6.5 \%$ of soybean meal, $7 \%$ of fish meal, $5 \%$ of wheat bran, $4.5 \%$ of defatted rice bran, $3 \%$ of alfalfa meal, $5.2 \%$ of calcium carbonate, $1.1 \%$ of calcium di-phosphate, $0.4 \%$ of salt, $0.05 \%$ of trace mineral premix and $0.25 \%$ of vitamin premix. The supplementation of the antibiotic premix was carried out by replacing wheat bran in the basal diet.

Hens and rearing: In Expt. 1, 59 White Leghorn hens of about 9 months old were divided into 4 groups, and 80 White Leghorn hens of about 10 months old were divied in to 7 groups in Expt. 2. Number of hens in each group in both of the experiments is presented in Table 1. Hens were reared in an individual cage and fed the experimental diets containing various levels of the antibiotic with free access for 7 days. On the 7 th days, all of the experimental diets were removed and the basal diet without antibioctic was fed to all of the hens for another 7 days in Expt. 1 and for 12 days in Expt. 2. 
All of the eggs produced during the experimental period were kept in polyethylene bag individually and stored in a refrigerator at $-20^{\circ} \mathrm{C}$. The eggs of 5 hens from each of the grcups, who laid continuously during the experimental period, were selected and sent to the National Veteriany Assay Laboratory for analysis of spiramycin.

In Expt. 2, 25 more hens of the same age were fed the experimental diet containing $1,000 \mathrm{ppm}$ of spiramycin for 7 days. Then, hens were divided into 5 groups of 5 hens each and fed spiramycin-free basal diet. Each of 5 groups was sacrificed at $0,2,4,6$ and 12 days after the withdrawal of spiramycin. Their livers were stored individually in a refrigerator at $-20^{\circ} \mathrm{C}$. for microbiological assay.

Microbiological assay: Irdividual egg white, egg yolk and liver were homogenized and diluted by 5 times with $0.1 \mathrm{~m}$ phosphare buffer solution of $\mathrm{pH} 8.0$. The content of spiramycin in the diluted sample was determined with Sarcina lutea ATCC 9341. The details of the assay were described in the previous paper ${ }^{1}$. Sensitivity of microbioassay was $0.45 \mu \mathrm{g}$ (potency)/g of sample.

Statistical analyses: Since only few hens laid every day throughout the experimental period, the antibiotic level in eggs when hen did not lay was estimated by the procedure to estimate the missing value in factorial experiment design ${ }^{2}$.

Although the microbioassay was carried out on the egg white and the egg yolk separately, statistical analyses were carried out on the content of whole egg. The content of antibiotic in whole egg was calculated from the contents in egg white and yolk, presuming that egg white composed of $63.8 \%$ of whole egg excluding egg shell and egg yolk composed of $36,2 \%$.

The spiramycin content of whole eggs laid during the feeding pericd of $500 \mathrm{ppm}$ of antibiotic in Expt. 1 was analyzed as split-plot design. The exprimental design of main experiment was one-factor design with 2 dietary levels of antibiotic and 5 repeats each. Each of the main plots, i. e. individual hen in this case, was split into 7 sub-plots, which actually corresponded to the days on the experimental diet.

The spiramycin content of whole eggs laid after the withdrawal of antibiotic in Expts. 1 and 2 was combined and analyzed also as split-plot design. The experimental design of main experiment was two-factor design with 2 dietary levels of antibiotic in 2 experiments with 5 repeats each. Each of the main plot, i. e. individual hen, split into 4 sub-plots, which actually corresponded to the days after the withdrawal of antibiotic.

After these variance analyses of split-plot designs, 4 regression analyses were carried out, (1) batween spiramycin level in whole egg and the days on experimental diets of 1,000 ppm of spiramycin in Expt. 1, (2) between spiramycin level in whole egg and the days after withdrawal of dietary spiramycin at the level of $500 \mathrm{ppm}$, (3) and of 1,000 ppm, and (4) between dietary spiramycin content and spiramycin level in whole egg on 7 th day on experimental diet in both of Expts. 1 and 2.

\section{Results}

In Table 1, number of hens, average egg production and average daily intake of feed and spiramycin in Expts. 1 and 2 are presented. Actually, no difference was observed in 
the performance of hens, indicating that spiramycin had little physiologically detrimental effect on egg production even at the highest level of $1,000 \mathrm{ppm}$. The findings may be agreeable with the previous observations ${ }^{1)}$ with broiler.

Spiramycin level in egg white and egg yolk in Expt. 1 is presented in Table 2, in which data on $500 \mathrm{ppm}$ was omitted to avoid complication. On $20 \mathrm{ppm}$ of dietary spiramycin only 2 eggs out of 58 tested was found to contain spiramycin in egg white alone at such a low level as to slightly exceed the the limit of detection, i. e. $0.45 \mathrm{ppm}$.

Table 1. Production record of hen on spiramycin

\begin{tabular}{ccccc}
\hline Dietary level & No. of hen & $\begin{array}{c}\text { Egg production } \\
\text { (hen-day) }\end{array}$ & Feed intake & $\begin{array}{c}\text { Spiramycin } \\
\text { intake }\end{array}$ \\
\hline ppm & & $\%$ & g/hen/day & mg/hen/day \\
0 & & 75 & 97 & 0 \\
50 & 15 & 71 & 101 & 5.0 \\
1,000 & 14 & 70 & 111 & 109.0 \\
Expt. $2:$ & 15 & 77 & 109 & 0 \\
0 & 15 & 79 & 115 & 1.8 \\
50 & 10 & 74 & 92 & 10.7 \\
100 & 12 & 73 & 167 & 21.4 \\
200 & 12 & 86 & 115 & 60.5 \\
1,000 & 12 & 71 & 121 & 108.0
\end{tabular}

Table 2. Spiramycin level (ppm) of egg white and egg yolk in Expt. 1.

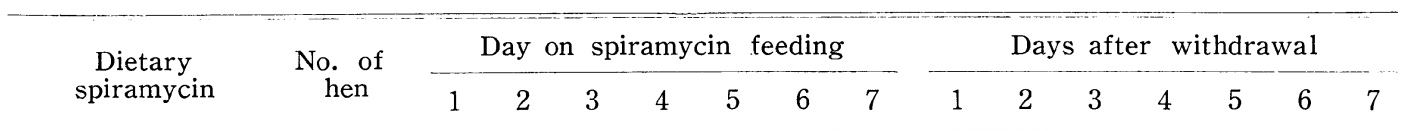

Egg white:

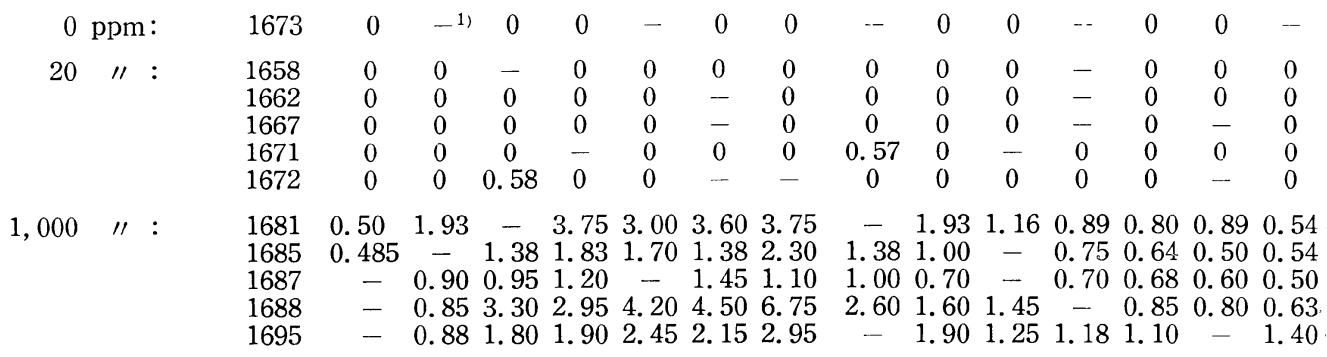

Egg yolk:

\begin{tabular}{|c|c|c|c|c|c|c|c|c|c|c|c|c|c|c|c|c|c|}
\hline 0 & ppm & & 1673 & 0 & - & 0 & 0 & - & 0 & 0 & - & 0 & 0 & $\ldots$ & 0 & 0 & - \\
\hline 20 & $\prime \prime$ & & $\begin{array}{l}1658 \\
1662 \\
1667 \\
1671 \\
1672\end{array}$ & $\begin{array}{l}0 \\
0 \\
0 \\
0 \\
0\end{array}$ & $\begin{array}{l}0 \\
0 \\
0 \\
0 \\
0\end{array}$ & $\begin{array}{l}- \\
0 \\
0 \\
0 \\
0\end{array}$ & $\begin{array}{l}0 \\
0 \\
0 \\
0\end{array}$ & $\begin{array}{l}0 \\
0 \\
0 \\
0 \\
0\end{array}$ & $\begin{array}{l}0 \\
- \\
\overline{0} \\
-\end{array}$ & $\begin{array}{l}0 \\
0 \\
0 \\
0 \\
-\end{array}$ & $\begin{array}{l}0 \\
0 \\
0 \\
0 \\
0\end{array}$ & $\begin{array}{l}0 \\
0 \\
0 \\
0 \\
0\end{array}$ & $\begin{array}{l}0 \\
0 \\
0 \\
- \\
0\end{array}$ & $\begin{array}{l}- \\
- \\
\overline{0} \\
0\end{array}$ & $\begin{array}{l}0 \\
0 \\
0 \\
0 \\
0\end{array}$ & $\begin{array}{l}0 \\
0 \\
\overline{0} \\
-\end{array}$ & $\begin{array}{l}0 \\
0 \\
0 \\
0 \\
0\end{array}$ \\
\hline 1,000 & $\prime \prime$ & : & $\begin{array}{l}1681 \\
1685 \\
1687 \\
1688 \\
1695\end{array}$ & $\begin{array}{l}0 \\
0 \\
- \\
- \\
-\end{array}$ & $\begin{array}{l}0 \\
0 \\
0 \\
0\end{array}$ & $\begin{array}{c}-\overline{5} \\
0.50 \\
0 \\
1.14 \\
0.77\end{array}$ & $\begin{array}{l}1.48 \\
1.23 \\
0.63 \\
1.70 \\
1.60\end{array}$ & $\begin{array}{c}3.00 \\
1.00 \\
- \\
1.60 \\
2.15\end{array}$ & $\begin{array}{l}1.48 \\
1.30 \\
0.63 \\
2.30 \\
2.45\end{array}$ & $\begin{array}{l}2.40 \\
2.15 \\
0.60 \\
6.00 \\
2.25\end{array}$ & $\begin{array}{c}-\overline{8} \\
0.53 \\
1.50 \\
-\end{array}$ & $\begin{array}{l}3.60 \\
1.70 \\
0.50 \\
1.60 \\
2.15\end{array}$ & $\begin{array}{c}1.25 \\
- \\
- \\
1.45 \\
1.18\end{array}$ & $\begin{array}{c}1.10 \\
1.00 \\
0 \\
- \\
1.05\end{array}$ & $\begin{array}{c}0.95 \\
0.85 \\
0 \\
1.00 \\
0.93\end{array}$ & $\begin{array}{c}0.64 \\
0.49 \\
0 \\
0.80 \\
-\end{array}$ & $\begin{array}{c}0 \\
0 \\
0 \\
0 \\
0.58\end{array}$ \\
\hline
\end{tabular}

1) No egg was laid. 
Only one egg out of 25 tested in Expt. 2 on the same dietary level contained spiramycin in egg white at a level of $0.48 \mathrm{ppm}$.

Transfer of dietary spiramycin at the level of $1,000 \mathrm{ppm}$ to the egg increased continuously and the highest value was obtained on the 7 th day. Thereafter, with withdrawal of dietary antibiotic, transfer of the antibiotic to eggs decreased. The large individual variation was observed in the amount of antibiotic transferred to egg. For example, hen No. 1688 had ability to transfer large amount of dietary antibiotic to eggs while hen No. 1687 had very low ability. On the 7 th day on spiramycin feeding, the egg from hen No. 1688 contained $6.75 \mathrm{ppm}$ of spiramycin in egg white, and thereafter the amount of transferred antibiotic decreased rapidly to $0.63 \mathrm{ppm}$ after 7 days on the withdrawal. On the other hand, the egg white from hen No. 1687 contained only $1.1 \mathrm{ppm}$ of spiramycin on the 7 th day on feeding spiramycin, which was about one sixth of that in the corresponding egg white of hen No. 1688. Amount of transferred spiramycin in the egg white of hen No. 1687 decreased very slowly after the withdrawal of antibiotic and reached $0.5 \mathrm{ppm}$, which was comparable to that in the egg white of hen No. 1688 on the same day.

Average spiramycin content in the whole egg of 5 hens each with missing value

Table 3. Average spiramycin content (ppm) of egg of 5 hens fed various levels of spiramycin.

\begin{tabular}{|c|c|c|c|c|c|c|c|c|c|c|c|c|c|c|c|}
\hline \multirow{2}{*}{$\begin{array}{l}\text { Dietary } \\
\text { spiramycin }\end{array}$} & \multicolumn{7}{|c|}{ Days on spiramycin feed } & \multicolumn{8}{|c|}{ Days after withdrawal } \\
\hline & 1 & 2 & 3 & 4 & 5 & 6 & 7 & 1 & 2 & 3 & 4 & 5 & 6 & 7 & 12 \\
\hline
\end{tabular}

Expt. 1:

$\begin{array}{rlcccccccccccccc}0 & \mathrm{ppm} & 0 & 0 & 0 & 0 & 0 & 0 & 0 & 0 & 0 & 0 & 0 & 0 & 0 & 0 \\ 20 & \prime \prime & 0 & 0 & 0.07 & 0 & 0 & 0 & 0 & 0.07 & 0 & 0 & 0 & 0 & 0 & 0 \\ 500 & \prime \prime & 0.17 & 0.83 & 1.14 & 1.35 & 1.49 & 1.47 & 1.76 & 1.45 & 1.41 & 1.03 & 0.95 & 0.64 & 0.52 & 0.39 \\ 1,000 & \prime \prime & 0.20 & 0.67 & 1.58 & 1.96 & 2.23 & 2.25 & 3.12 & 1.66 & 1.60 & 1.06 & 1.03 & 0.79 & 0.70 & 0.50\end{array}$

Expt. 2:

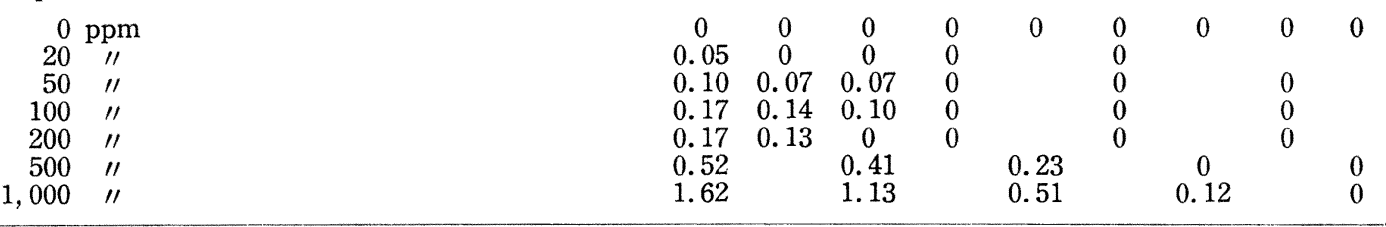

Table 4. Variance analyses on split-plot experimental design

\begin{tabular}{|c|c|c|c|c|c|}
\hline \multirow{2}{*}{\multicolumn{2}{|c|}{ Factor }} & \multicolumn{2}{|c|}{ Feeding period } & \multicolumn{2}{|c|}{ After withdrawal } \\
\hline & & $\begin{array}{l}\text { degree of } \\
\text { freedom }\end{array}$ & Variance & $\begin{array}{l}\text { degree of } \\
\text { freedom }\end{array}$ & Variance \\
\hline Dietary level & A & 1 & 5.20 & 1 & 5.34 \\
\hline Experimental No. & - $\quad \mathrm{Y}$ & & & 1 & 13.82 \\
\hline Interaction & $\mathrm{A} \times \mathrm{Y}$ & & & 1 & 0.08 \\
\hline Individual error & $\mathrm{e}_{1}$ & 8 & 4.93 & 16 & 3.09 \\
\hline Days on or after & : $\quad \mathrm{D}$ & 6 & $5.78^{* *}$ & 3 & $7.79 * *$ \\
\hline Interaction & $\mathrm{A} \times \mathrm{D}$ & 6 & 0.63 & 3 & $1.20^{*}$ \\
\hline Interaction & $\mathrm{Y} \times \mathrm{D}$ & & & 3 & 0.67 \\
\hline Secondary error & $\mathrm{e}_{2}$ & 48 & 0.36 & 51 & 0.41 \\
\hline
\end{tabular}

**, *: Significant at 1 and $5 \%$ levels, respectively. 
estimated as mentioned above is presented in Table 3. The content of spiramycin in the eggs, which are not presented in Table 3, was not determined in these experiments.

Spiramycin content of the whole egg laid during the period of feeding spiramycin at dietary levels of 500 or $1,000 \mathrm{ppm}$ in Expt. 1 were analyzed statistically. The result of variance analysis is shown in Table 4. Individual error was significantly higher than the secondary error, which corresponded the daily variation of spiramycin content in the egg of the same hen fed the same diet. The effect of dietary level of spiramycin was fairly large, but was not significant statistically, since it was tested against relatively large individual error. On the other hand, effect of the days on spiramycin feeding was highly significant. This effect was further divided into linear, quadratic and higher order effects. and it was found that the linear effect was highly significant, suggesting that spiramycin content of eggs was in direct proportion with the length on the diet containing the antibiotic. The following equation 1 was found fit to describe the relationship:

$$
y=0.449 T_{1}
$$

where, $y$ is spiramycin content of whole egg ( $\mathrm{ppm})$ and $T_{1}$ days on spiramycin feeding.

Spiramycin content of whole egg laid at $0,2,4$ and 6 days after the withdrawal of dietary spiramycin at the level of 500 or $1,000 \mathrm{ppm}$ in both of the experiments were combined and analyzed statistically. The result of variance analysis is shown in Table 4, Again, significantly higher individual error variance than secondary error was obtained. Main effects between dietary spiramycin levels and between the experiments were fairly large but were not significant statistically. Main effect of days after the withrawal was highly significant. The interaction $\mathrm{A} \times \mathrm{D}$ was significant so that the data on two dietary level should be analyzed separately in further analysis.

Since the previous variance analysis on the data obtained in Expt. 1 revealed that the declining tendency of the amount of transferred antibiotic in the eggs after the withdrawal of dietary antibitiotic was exponential, relationship between days after the withdrawal of spiramycin and logarithm of spiramycin content in whole egg was studied. The following Equations 2 and 3 were found fit to describe the declining tendency,

$$
\begin{aligned}
& \log y_{1}=0.1389-0.1214 T_{2} \\
& \log y_{2}=0.3825-0.1268 T_{2}
\end{aligned}
$$

where, $y_{1}$ and $y_{2}$ are spiramycin centent in whole egg at dietary levels of 500 and 1,000 ppm, respectively, and $T_{2}$ is days after the withdrawal of dietary spiramycin. The Equations 2 and 3 are transformed into Equations 4 and 5, respectively.

$$
\begin{aligned}
& y_{1}=1.48 e^{-0.2795 T_{2}} \\
& y_{2}=2.41 e^{-0.2920 T_{2}}
\end{aligned}
$$

Highly significant correlation coefficient of 0.9995 was obtained for Equation 3. However, the correlation coefficient for Equation 2 was 0.9471 , which was not signifiacant statistically. This was mainly due to smallness of size of the experiment, but it was also suggested. that the dietary level of $500 \mathrm{ppm}$ of spiramycin might not be high encugh to detect: statistically the exponentially declining tendency against fairly large error variance.

On the average spiramycin content of the eggs of 5 hens on the 7 th day of spiramycin! feeding, the following Eqbation 6 was induced,

$$
v=0.002436 x-0.0847
$$


Table 5. Content of spiramycin in liver of laying hen fed a diet containing $1,000 \mathrm{ppm}$ of spiramycin

\begin{tabular}{crccl}
\hline \multicolumn{5}{c}{ Days after withdrawal } \\
\hline 0 & \multicolumn{1}{c}{2} & 4 & 6 & 12 \\
\hline $\mathrm{ppm}$ & $\mathrm{ppm}$ & $\mathrm{ppm}$ & $\mathrm{ppm}$ & $\mathrm{ppm}$ \\
72.5 & 12.75 & 0.75 & 0.58 & 0 \\
425.0 & 5.25 & 1.40 & 0.58 & 7.53 \\
10.00 & 24.00 & 1.53 & 0.50 & 2.40 \\
35.00 & 12.75 & 4.20 & 0.85 & 0 \\
16.5 & 2.88 & 2.55 & 1.08 & 0 \\
\hline
\end{tabular}

where, $y$ is spiramycin concent in whole egg (ppm) and $x$ is dietary level of spiramycin (ppm). Highly significant correlation coefficient, 0.9025 , revealed that amount of antibiotic transferred from diet to eggs was in direct proportion to dietary level of antibiotic.

Content of spiramycin in the liver of laying hen fed 1,000 ppm of dietary spiramycin determined at $0,2,4,6$ and 12 days after the withdrawal of dietary spiramycin is shown in Table 5. Unexpectedly large variation was otserved among the liver content of spiramycin of the individual hen. At 0 day, the content of spiramycin in the liver was from 425 to $10 \mathrm{ppm}$. Even at 12 days after the withdrawal, 7.53 and $2.40 \mathrm{ppm}$ of spiramycin was observed in the liver of 2 hens out of 5 , while no spiramycin was detected in the liver of the rest of the hens. Taking logarithm of spiramycin content, the following Equation 7 was obtained to describe the relationship,

$$
\log y=1.1507-0.1258 T_{2} \text {. }
$$

where, $y$ is the content of spiramycin in the liver and $T_{2}$ is the days after the termination of spiramycin feeding. In this regression analysis after logarithm transformation, 0.45 ppm, i, e, the sensitive limit of the microbioassay, was taken instead of 0 valune on the 12 th day. Tne correlation coefficient was -0.670 , which was highly significant statistically.

The Equation 7 can be transformed into Equation 8.

$$
y=11.53 e^{-0.2898 T_{2}} \text {. }
$$

\section{Discussion}

Transfer to and disappearance from the eggs of dietary spiramycin could be explained by 3 equations, i. e. Equations 1.5 and 6 . Combining these findings, a very important proposal can be made on the over-all behavior of dietary antibiotic. The transfer to and disappearance from the eggs of antibiotic could be explained by an Equaton 9,

$$
y=(a+b x) T_{1} \cdot e^{-c T_{2}}
$$

where, $y$ is antibiotic content in whole egg, $x$ dietary level of antibiotic, $T_{1}$ days on the diet containing antibiotic, $T_{2}$ days after termination of feeding antibiotic and $a, b$ and $c$ are constants. During the feeding period of antibiotic, $T_{2}$ should be zero and after the termination of antibiotic feeding $T_{1}$ should be a fixed value. For spiramycin, $a, b$ and $c$ are estimated to be $-0.0121,0.000348$ and 0.292 , respectively, from Equations 1,5 and 
6. Thus, the amount of spiramycin in an egg can be estimated, if $x, T_{1}$ and $T_{2}$ are given, i. e. if it is known how much spiramycin is in the diet, how long the diet is fed to the hen and how long it is after the withdrawal of the antibiotic from the diet.

Constants $a, b$ and $c$ in Equation 9 should be specific to each antibiotic. Constants a and $b$ indicate the easiness to be absorbed by the hens and to be transferred into the eggs. The constant $c$ indicates the rapidness of disappearance of the antibiotic from the eggs. Biological half life of an antibiotic in the eggs can be estimated as $\log _{\mathrm{e}} 2 / c$, which certainly reflect the biological half life of antibiotic in the hens body, since the amount of antibiotic in the eggs laid each day should be in direct proportion to that in the hens body. Further experiments are planned by the authors to $\epsilon$ stimate the constants, $a, b$ and $c$ for various antibiotics. These experiments will reveal the biological characteristics of antibiotics and will suggest the way to use them effectively without fear on the transferred antibiotics in the eggs.

Biological half lives $\epsilon$ stimated from the data on the egg and on the liver are presented in Table 6. Fiducial intervals shown in this table looked like wide, mainly because of relatively large individual variation. However, average values of biological half life of spiramycin estimated from the egg, the liver of hen and the liver of broiler were very close, suggesting the usefulness of biological half life as an indicator to show the speed of disappearance of antibiotic from chicks body. Although biological half life of chlortetracycline was estimated from only 3 data as mentioned in the previcus paper ${ }^{1}$, the average value, 0.8 days is far below the lower fiducial limit of biological half life of spiramycin. The finding clearly indicates the difference in biological characteristics between spiramycin and chlortetracycline.

Unexpectedly large individual variation in the content of antibiotic in the liver and the egg should be kept in mind in the analysis and interpretation of the data. Logarythmic transformation of the estimates is ceratainly effective to make the distribution of the estimates close to the normal distribution, on which the statistical analysis is based. Being disturbed by this large individual variation, the data on $500 \mathrm{ppm}$ of spiramycin are not so clear-cut as those on $1,000 \mathrm{ppm}$ of spiramycin in the interpretation of linear and exponential change of the amount of spiramycin in the egg during and after feeding

Table 6. Biological half life of spiramycin and chlortetracyclin estimated from egg and liver

\begin{tabular}{|c|c|c|c|}
\hline & Biological half life & $\begin{array}{l}95 \% \\
\text { fiducial limit }\end{array}$ & Note \\
\hline Spiramycin: & Days & Days & From \\
\hline Egg & 2.4 & $4.70-1.59$ & Equation 5 \\
\hline Liver (hen) & 2.4 & $4.57-1.62$ & Equation 8 \\
\hline Liver (broiler) & 2.0 & & $\begin{array}{l}\text { Equation } 2 \text { of } \\
\text { previous paper }{ }^{1)}\end{array}$ \\
\hline \multicolumn{4}{|l|}{ Chlortetracyline: } \\
\hline Liver (broiler) & 0.8 & & $\begin{array}{l}\text { Equation } 1 \text { of } \\
\text { previous paper }\end{array}$ \\
\hline
\end{tabular}

1) See literature 1. 
the antibiotic. In the experiments to estimate the biological characteristics of antibiotic, i.e. the constants, $a, b$ and $c$, dietary level of antibiotic tested should be high enough to understand the behavior of antibiotic exactly.

\section{Summary}

Spiramycin was fed to layers at various dietary levels from 20 to $1,000 \mathrm{ppm}$ for 7 days, and then dietary spiramycin was withdrawn and basal diet was fed for another 7 or 12 days. Spiramycin content in white and yolk of eggs laid by individual hen during and after the feeding period of spiramycin was analyzed microbiologically. Five hens. each day fed $1,000 \mathrm{ppm}$ of spiramycin were sacrificed at $0,2,4,6$ and 12 days after the withdrawal of dietary antibiotic for microbioassy of spiramycin content in the liver.

The amount of spiramycin transferred into egg increased linearly with days on the antibiotic and increased also in proportion to dietary level of spiramycin. After the termination of antibiotic feeding, spiramycin in the egg decreased exponentially. Spiramycin content in liver decreased also exponentially after the withdrawal of dietary spiramycin. From these findings, an equation is introduced, by which spiramycin level in an egg laid on a certain day can be predicted. Biological half life of spiramycin in chicks body is estimated to be 2.4 days from the egg, which is agreeable to that estimated from the liver.

\section{Literature}

1) Yoshida, M., S. Yonezawa, H. Nakamura, H. Azechi, N. Terakado and T. Horiuchi, Japan. Poultry Sci., 8, 94, 1971.

2) Davies, O.L., The design and analysis of industrial experiments 2nd Ed., p. 235, Oliver and Boyd, London 1956.

\section{飼料中のスピラマイシンの鶏卵中への移行ならびに} 産卵鶏の肝臓中の残留について

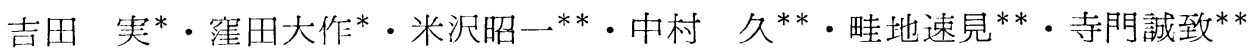

スピラマイシン含量が $20 \sim 1,000 \mathrm{ppm}$ の飼料を産卵鶏

に7日開与手え, その後, 抗生物質無添加飼料に切替え

て，7もしくは 12 月閒飼公した。この閒に産卵した卵

の, 卵白と卵黄中のスピラマイシン含量を, 個体別に微

生物定量法により測走した。また，抗生物質の投与中止

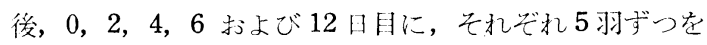

殺して, その肝蔵中のスピラマイシン含舅を個体別に測

公した。

鶏卵中へのスピラマイシンの移行量は, 飼料中の含量

* 譨林省畜產試験場, 千藮市

** 農林省動物医薬品検査所, 国分寺讯
と，投与日数とに比例して直線的に増加していた。投与 中止後, 鶏卵中のスピラマイシンは指数曲線的に減少し ていた。

投与中止後の肝臓中のスピラマイシンも, 同様に指数 曲線的に減少していた。これらの知見から，ある日に産 んだ鷄卵中の大ピラマイシン含量を子測する計算式が導 かれた。また, 鷄体内のスピラマイシンの生物学的半減 期注, 鵎卵のデータから 2.4 日と推定され，これは朋臓 のデータからの推尘储と一致していた。

（家禽会誌，8，103～110，1971） 